\title{
Original References for WPS Vol. 15, Issue 1 (2019) articles
}

https://doi.org/10.1515/wps-2019-2501

1.

"Governing European Affairs"

Author(s): Jarle Trondal/Nadja Kuhn

In Norwegian:

Trondal, J. \& Kühn, N. (2018) "Norsk Europaforvaltning. Et organisasjonsteoretisk perspektiv på departementenes EU arbeid.” Norsk statsvitenskapelig tidsskrift. 34(02-03): 46-64.

In English:

Trondal, J. \& Kühn, N. (2018) “Governing European Affairs.” Lessons from Norwegian ministries. Norwegian Journal of Political Science. 34(02-03): 46-64.

2.

"How Regulation Effects Corporate Social Responsibility: Corporate Environmental Performance under Different Regulatory Scenarios” Author(s): Orr Karassin/Aviad Bar-Haim

Social security, 105 (August) 2018 pp. 17-50

3.

"Regional Alliance Structure and International Conflict" Author: Kentaro Sakuwa

Sakuwa, Kentaro. 2017. “Chiiki no Dōmei Kōzō to Kokusaifunsō [Regional Alliance Structure and International Conflict].” Kokusaiseiji [International Relations] 189: 33-48. (in Japanese)

4.

"A rising tide that lifts no boats. The European Union and the development of the transnational economy of crimigration"

Author: Marek Rewizorski

Rewizorski, Marek (2016). “Przypływ który nie unosi żadnej łodzi. Unia Europejska wobec transnarodowej ekonomii krymigracyjnej.” Rocznik Integracji Europejskiej, No.10: 191-211, DOI : 10.14746/rie.2016.10.12 http://rie.amu.edu.pl/?page_id=367 
5.

"The Foundations of Freedom and Civilization: the Durham Report, municipal institutions and the liberalism"

Author: Benoit Morissette

Morissette, Benoît. 2017. “ «Les fondements de la liberté et de la civilisation »: le rapport Durham, les institutions municipales et le libéralisme.” Canadian Journal of Political Science/Revue canadienne de science politique 50(4): 955-981. 